\title{
Reflection on Strengthening Specialty Construction of Local Application-oriented University
}

\author{
Zhang ying ${ }^{1 \text {, a }}$ \\ ${ }^{1}$ Jilin business and technology college, 130062, China \\ aemail: 632537303@qq.com
}

Keywords: Specialty construction; Local; Application-oriented University

\begin{abstract}
Specialty construction is an important foundation of talent training in colleges and universities and is also an important content of university construction; besides, its construction level determines the quality and standard of talent training and reflects schooling capability and schooling level. In this thesis, research is conducted on specialty construction of local application-oriented university from the thoughts, contents and measures of specialty construction, and it is found that local university serves local economic and social development and plays a part in the local economic construction and thus the developments and constructions of all the aspects should be strengthened continuously.
\end{abstract}

\section{Thought of Consolidation of Specialty Construction in Local Application-oriented University}

According to the positioning of local application-oriented university in higher education system, its service object is the local social and economic development. Hence, in the specialty construction, demands of regional industrial structuring and optimization and upgrading on talent training should be adapted actively and the professional foundation should be strengthened and specialty orientation should be extended on the basis of demands of regional social and economic development while the running principle of college is insisted; besides, subject integration should be further intensified and characteristic specialties should be cultivated when attention is paid to the traditional dominant specialties and also specialty construction should be developed hierarchically, taxonomically and designedly according to schooling conditions, discipline development and the practical condition of teaching staff so as to form the specialty structure system with distinctive characteristics of the times.

\section{A. Reforming and Promoting Traditional Dominant Specialties}

For the old specialties that have certain traditional advantages, the advantages of the traditional subjects including strong professional faculty, rich schooling experience and abundant instructional resources should be brought into play and simultaneously the teaching contents should be updated and course system should be reformed firstly; secondly, more high and new technologies and information sciences and other modern science and technologies should be utilized to promote and reform traditional specialties so that the new development of traditional subjects can be realized, new subjects can be derived and construction of new specialty can be mobilized; thirdly, reformation should be conducted actively on the basis of existing conditions to maintain the distinguishing features and fine traditions of the specialty in order that the exuberant vigor of basic subjects can be retained.

\section{B. Strengthening Construction of New Specialties}

The local universities should declare and construct new specialties actively after combining with the practical condition of local social and economic development: firstly, the financial support on new specialties should be emphasized and necessary specialized teachers should be imported or trained one year before the enrollment of the new specialties according to the annual plan of specialty construction; secondly, preferential treatments should be afforded for the manning quotas of the new specialty, evaluation and employment index of the title, professional development at 
home and abroad, academic exchange and data and equipment and high level professional talents should be trained and imported designedly to solve teacher shortage problem of new specialties; thirdly, cost should be input to improve the teaching condition of new specialties, especially the construction of laboratories; fourthly, teaching and research, course book and course construction should be intensified and the new teachers should be encouraged to conduct teaching research, teaching material construction and excellent course construction through declaring the construction projects on teaching and research, course book, teaching materials and excellent course; fifthly, supervision and inspection on new specialty construction should be strengthened and attention should be paid to the construction of new specialties; besides, the progress of new specialty construction should be grasped at all times and problems should be solved timely through routine inspection and random inspection to guarantee the construction quality of the new specialties.

\section{Promoting Construction of Characteristic Specialties}

Characteristic specialty refers to the specialty that embodies the running principle of college, including educational objective, teaching staff, course system, teaching condition and cultivation quality and also has higher schooling level and distinctive school-running characteristics and higher social reputation and is also identified by the society. The characteristics in "characteristic specialty" should at least include course characteristic, teaching characteristic and talent characteristic, among which, talent characteristic is key aspect. Along with the rapid development of society and economy, competitive force of college is further reinforced and the specialty construction of universities of all the colleges and universities are accelerated.

\section{Content of Consolidation of Specialty Construction in Local Application-oriented University}

\section{A.Optimizing Professional Talent Training Plans}

The formulation and optimization of talent training plan is core content of specialty construction, including the necessary course system for realizing educational objective, teaching content, teaching approach and practice teaching and other basic contents. The first step for specialty construction is to formulate the training program that accords with the demands of society on application-oriented talents and the practical condition of the university and the training regularity of professional talents. Hence, the training mode of professional talents according with the practical condition of the university should be probed to optimize the training program of professional talents and improve the training quality of professional talents firstly. The focus of instructional university is on the cultivation of application-oriented talents, therefore, for the selection of talent training mode, practice should be consolidated and importance should be attached to the cultivation of practical skills; secondly, the training program of professional talents should be perfected ceaselessly, namely, the talent training objective should be determined and the course system should be regulated in time according to the demands of society on professional talents to lay a good foundation for the talents to adapt to the social and economic development.

\section{B.Deepening the Reform in the Contents of Course Teaching}

Course construction is the main content of specialty construction and the proportion of all the courses in the course system are determined reasonably in the course construction by the local instructional universities according to the running principle of college and objectives of specialty construction. Therefore, attention should be paid to the proportion of foundation courses and specialized courses, required courses and elective courses, theory teaching and practical teaching when constructing the course system so that the scientific and ordered specialized course system with rational construction is formed firstly; secondly, the training characteristic of professional talents should be further highlighted based on the principle that foundation courses should be emphasized, main courses should be strengthened and elective courses should be extended; thirdly, reform of teaching content should be promoted actively so that the new and front excellent academic achievements in the field of the subject can be reflected in the teaching content; fourthly, the triune three-dimensional course book construction of course book, reference for teaching and teaching courseware should be strengthened and excellent course book of high quality should be 
selected.

\section{C.Reinforcing the Construction of Professional Teaching Staff}

For the enhancement of the construction of teaching staff in local instructional university, the completeness of teaching staff, improvement of their education background and rationalization of title structure should be emphasized firstly for the construction of traditional professional teaching staff and the enhancement of education background of the teaching staff should be considered as the main way; secondly, for the construction of the teaching staff of experimental teaching and engineering course, importance should be attached to the cultivation of double capability trainer who should be able to teach professional courses and instruct experiment and practice; thirdly, for the construction of new professional teaching staff, greater efforts should be devoted to introduction and cultivation and reasonable teaching staff should be formed quickly to ensure the stable improvement of professional teaching quality. Meanwhile, great attention should be paid to the selection and cultivation of excellent young and middle-aged backbone teachers and reserve talents and young and middle-aged teachers should be encouraged to study for doctor's degree or master's degree and to participate in continuing professional development of higher level.

\section{D.Emphasizing Practice Teaching Reform}

Practice teaching is an important link of teaching and is also the main method for training the practical ability of students and enhancing the practical skill of students. Furthermore, construction of laboratory and practice base is the precondition for improving innovation ability of students. For the reform on practice teaching and construction of laboratory and practice base, special attention should firstly be paid to reinforcement of practice teaching and reform on experimental teaching contents and experimental teaching methods and also the experimental teaching system should be built, which is composed of basic experiment, comprehensive experiment, innovative experiment and investigation test; secondly, the mode that promotes teaching through research projects should be probed and the research results and research thinking should be infused into experimental teaching to help the students extend knowledge and vision, strengthen team work spirit and develop scientific thinking method and enhance practical capacity. Thirdly, construction of laboratories in school should be strengthened, that is to say, the construction level of laboratories should be enhanced while the basic experiment teaching is satisfied; fourthly, construction of practice base should be strengthened; practice base on campus should be extended and the principle for combining teaching function and scientific research function of the base should be insisted to build a number of stable practical bases off campus specifically through applying the method of college and enterprise joint so that the important function of specialty construction in the practice base can be brought into full play and advantages can be created for improvement of practical ability and initiative spirit of students.

\section{Measures for Consolidation of Specialty Construction in Local Application-oriented University}

\section{A.Formulating Scientific and Reasonable Specialty Construction Plans}

The formulation of scientific and reasonable professional plan is the premise of specialty construction. Firstly, the schooling level and positioning of the university should be taken fully into account. The schooling level of the university can reflect the positioning of the university in the whole higher education system and also it involves the level and standard of the talent training in the university. Moreover, the positioning of the university can reflect the schooling type and orientation of the university and also it involves the school type and discipline structure. If it is seen from the position of local instructional university in the higher education system, its main focus is on the cultivation of application-oriented talents needed by local economic construction; meanwhile, school type should be taken into account and the professional plan should be completed with focus; secondly, the original subjects and the specialty construction foundation should be considered adequately. The specialty construction of the university is the inheritance and development of the 
original subjects. Thirdly, the professional structures and instructional resources of the available teaching staff should be fully considered. Teaching staff and instructional resources are the guarantee of specialty construction and the orientation and level of specialty construction are determined by the professional structure and quality of the teaching staff.

\section{B.Strengthening Evaluation on Specialty Construction}

Professional evaluation is the basis for understanding the problems in specialty construction and specialty development, putting the ideas of specialty construction into shape, strengthening the basic construction of teaching, deepening reform in education, forming specialty characteristics and regulating specialty; besides, it is also the important link for specialty construction. Hence, professional evaluation system should be perfected firstly in order to strengthen the evaluation of specialty construction. First of all, professional evaluation institution should be built and professional evaluation leading group of the school and professional evaluation expert group of relevant subject should be set up; in the next place, scientific and effective professional evaluation program should be formulated. Professional evaluation program is the ruler for professional evaluation and the scientificity of the professional evaluation program is related with the validity and credibility of the professional evaluation and also influences the results of the whole professional evaluation. Secondly, the professional evaluation process should be regulated. The purpose of professional evaluation is to promote specialty construction and thus it can not be a mere formality. Thirdly, professional evaluation results should be emphasized. Professional evaluation result is the basis for finding the problems in specialty construction, deepening reform in education and specialty construction; besides, it is related with the factors including construction of teaching staff, reform in education, investment on specialty construction, formation of specialty characteristics and utilization of instructional resources. Therefore, for the local instructional university, professional evaluation should not only be the material for professional rating or the measurement on the quality of colleges with specialty, instead, the professional evaluation results should be considered as the foundation for promoting specialty construction level, deepening reform in education, improving talent quality, forming specialty characteristics and improving school management and other work.

\section{Summary}

It is an important measure for stimulating advanced school principal, deepening reform on talent training mode and improving talent training quality to launch specialty construction step by step in a planned way. As the major power to serve local economic construction, local application-oriented university strengthens the talent training quality and improves the professional talent training capacity through specialty construction. Consequently, local economic construction and actual condition of local university should be combined, the plan should be scientific, the professional structure should be rational and the specialty construction should be strengthened, which is of great significance to the local university and the economic development of the region where the university is located.

\section{References}

[1] Liangyuan liu. Enhance the characteristics of local instructional undergraduate courses construction measures [J].China Electric Power Education. 2010.

[2] Yiliang yu. High quality of teaching as the core to strengthen the construction of teaching team[J].Education Forum.2010

[3] Yangzhou. To strengthen the professional connotation construction to strengthen teaching management[J].Academy of Management Journal.2010

[4] Huasheng tang. On Characteristic Specialty Construction of Newly-established Colleges[J]. Journal of Southwest University for Nationalities.2009

[5] Study on the analysis of internal and external causes of young college teachers. Education Exploration.2011 